\title{
The Western Wind and Solar Integration Study Phase 2
}

\section{An examination of how wind and solar power affect operations, costs, and emissions from fossil-fueled generators}

The electric grid is a highly complex, interconnected machine. Changing one part of the grid can have consequences elsewhere. Adding variable renewable generation such as wind and solar power affects the operation of the other types of power plants, and adding high penetrations can induce cycling of fossil-fueled generators. Cycling leads to wear-and-tear costs and changes in emissions, but do those increases in costs and emissions from cycling negate the overall benefits of integrating renewables?

Phase 2 of the Western Wind and Solar Integration Study (WWSIS-2) was initiated to determine the wear-and-tear costs and emissions impacts of cycling and to simulate grid operations to investigate the detailed impacts of wind and solar power on the fossil-fueled fleet in the West. It was a follow-up to Phase 1 (WWSIS-1), released in May 2010, which examined the viability, benefits, and challenges of integrating high penetrations of wind and solar power into the Western grid. WWSIS-1 found it to be technically feasible if certain operational changes could be made, but it raised questions regarding the impact of cycling on wearand-tear costs and emissions.

\section{Purpose of the Study}

Frequent cycling of fossil-fueled generators can cause thermal and pressure stresses. Over time, these can result in premature component failure and increased maintenance and repair. Starting

\begin{tabular}{|l|l|}
\hline \multicolumn{2}{|c|}{ Five Hypothetical Scenarios } \\
\hline No Renewables & $0 \%$ wind, 0\% solar \\
\hline TEPPC $^{*}$ & $9.5 \%$ wind, 3.5\% solar \\
\hline High Wind & $25 \%$ wind, 8\% solar \\
\hline High Solar & $25 \%$ solar, 8\% wind \\
\hline High Mix & $16.5 \%$ wind, 16.5\% solar \\
\hline $\begin{array}{l}\text { * Transmission Expansion Planning Policy Committee of the Western } \\
\text { Electricity Coordinating Council }\end{array}$ \\
\hline
\end{tabular}

"The increase in plant emissions from cycling to accommodate wind and solar generation are more than offset by the overall reduction in $\mathrm{CO}_{2}, \mathrm{NO}_{x^{\prime}}$ and $\mathrm{SO}_{2}$. Our analysis using real-world data shows that in highpenetration scenarios net carbon emissions were reduced by approximately one-third." - Debra Lew, PhD

a generator or increasing its output can increase emissions compared to noncyclic operations. Further, operating a generator at part-load can affect emissions rates. Utilities are concerned that cycling impacts can significantly negate the benefits that wind and solar power bring to the system. To plan accordingly, power plant owners need to understand the magnitude of cycling impacts.

\section{Key Findings}

- The negative impact of cycling on overall plant emissions is relatively small. The increase in plant emissions from cycling to accommodate variable renewables are more than offset by the overall reduction in $\mathrm{CO}_{2}, \mathrm{NO}_{\mathrm{x}}$, and $\mathrm{SO}_{2}$. In the high wind and solar scenario, net carbon emissions were reduced by one third.

\begin{tabular}{|c|c|c|}
\hline \multicolumn{3}{|c|}{$\begin{array}{c}\text { Emission Impacts of Cycling Are Relatively } \\
\text { Small Compared to Emission Reductions } \\
\text { Due to Renewables }\end{array}$} \\
\hline & $\begin{array}{l}\text { Emission Reduction Due } \\
\text { to Renewables }\end{array}$ & Cycling Impact \\
\hline $\mathrm{CO}_{2}$ & $\begin{array}{c}260-300 \text { billion lbs } \\
29 \%-34 \%\end{array}$ & Negligible Impact \\
\hline $\mathrm{NO}_{\mathrm{x}}$ & $\begin{array}{l}170-230 \text { million Ibs } \\
16 \%-22 \%\end{array}$ & 3-4 million lbs \\
\hline $\mathrm{SO}_{2}$ & $\begin{array}{l}80-140 \text { million lbs } \\
14 \%-24 \%\end{array}$ & 3-4 million lbs \\
\hline \multicolumn{3}{|c|}{$\begin{array}{l}\text { The increase in plant emissions from cycling to accommodate } \\
\text { variable renewables are more than offset by the overall reduction } \\
\text { in } \mathrm{CO}_{2}, \mathrm{NO}_{x^{\prime}} \text { and } \mathrm{SO}_{2} .\end{array}$} \\
\hline
\end{tabular}


- Operating costs increase by $2 \%$ to $5 \%$ on average for fossil fueled plants when high penetrations of variable renewables are added to the electric grid. From a system perspective, these increased costs are relatively small compared to the fuel savings associated with wind and solar generation.

- Wind and solar impact gas and coal plants very differently. Adding $4 \mathrm{MWh}$ of renewable generation displaces $1 \mathrm{MWh}$ of coal generation and $3 \mathrm{MWh}$ of gas. Wind tends to reduce generation from combustion gas turbines, while solar tends to increase starts and ramps of gas turbines to meet peaks that occur at sunset. The most significant cycling impact from increased wind and solar is the increased ramping of coal plants.

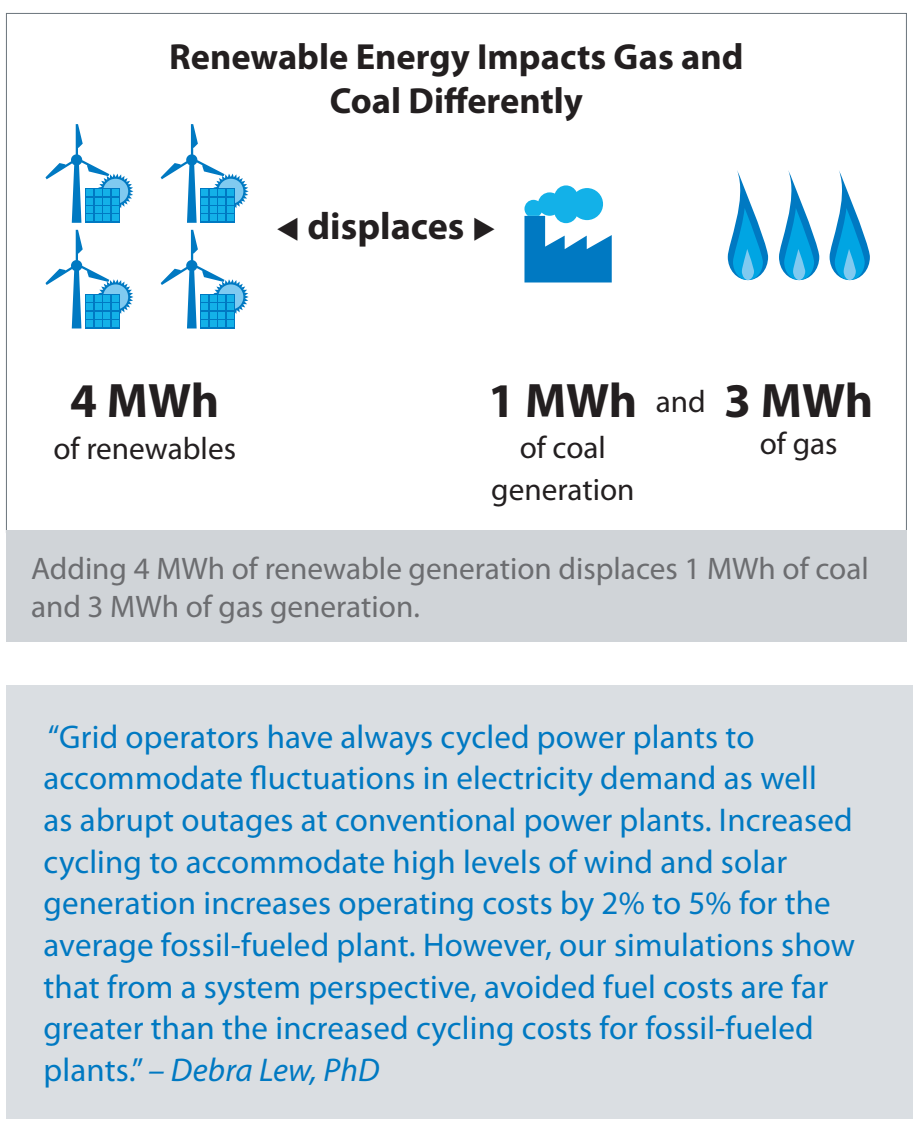

\section{Cycling Cost from Fossil-Fueled Generator Perspective}

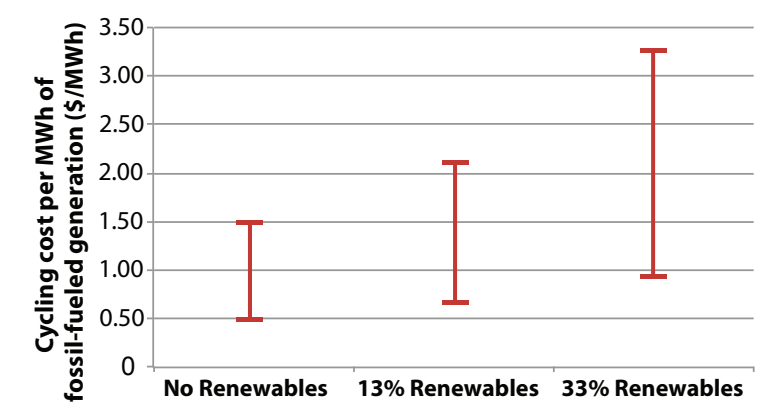

From a fossil-fueled generator perspective, cycling costs increase with increased wind and solar penetration.

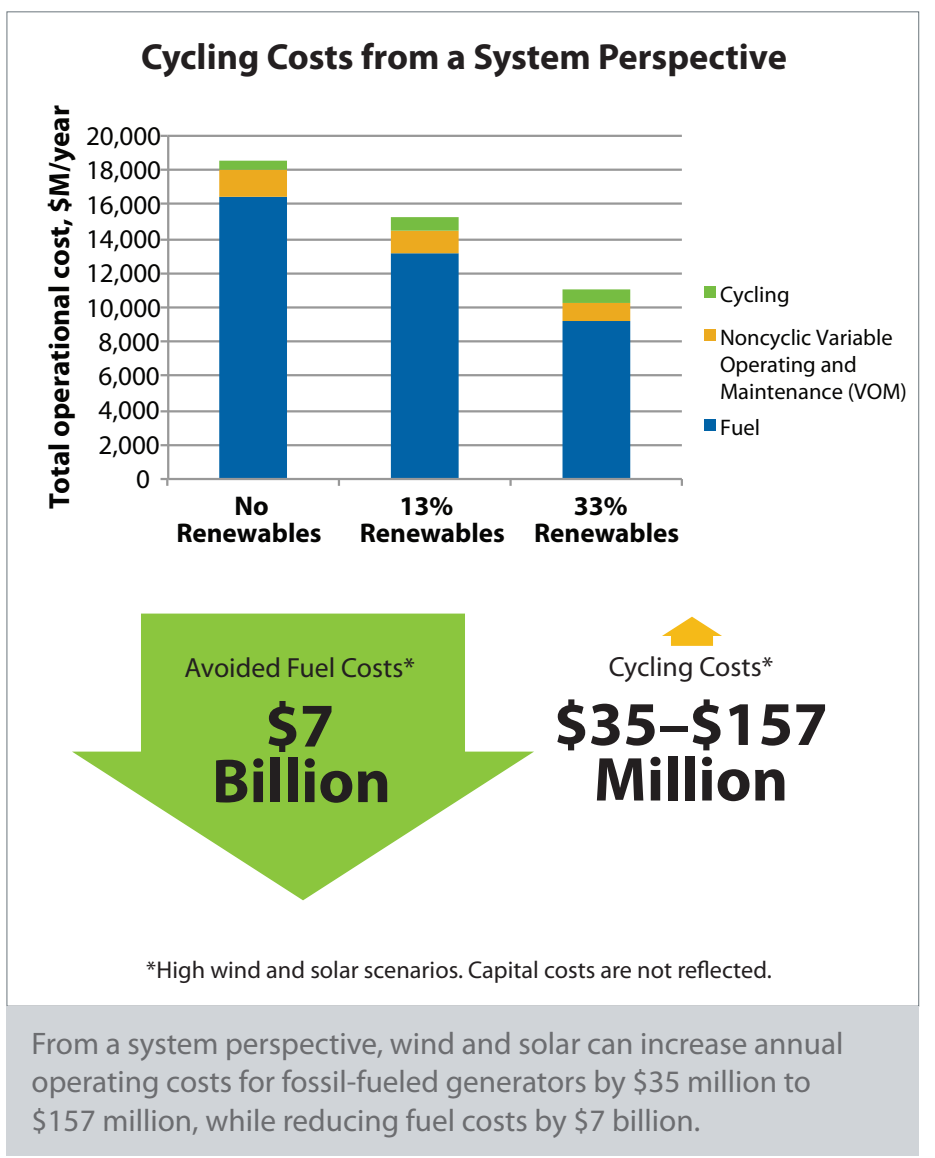

\section{INREL \\ NATIONAL RENEWABLE ENERGY LABORATORY}

National Renewable Energy Laboratory

15013 Denver West Parkway

Golden, C0 80401

303-275-3000 • www.nrel.gov
NREL is a national laboratory of the U.S. Department of Energy, Office of Energy Efficiency and Renewable Energy, operated by the Alliance for Sustainable Energy, LLC.

NREL/FS-5500-57874 • September 2013

Photos credits (page 1, left to right): iStock 13737597; Sunpower, NREL 08466; Warren Gretz, NREL 10926; Dennis Schroeder, NREL 21499; Warren Gretz, NREL 10930; Dennis Schroeder, NREL 19163

Printed with a renewable-source ink on paper containing at least 50\% wastepaper, including $10 \%$ post consumer waste. 